Article

\title{
Fracture Energy and Fracture Morphology after Three-Point Bending Test of Welded Joints Made of Cast Steel Designed for Use in Power Sector, with and without the Addition of Rare Earth Metals
}

\author{
Justyna Kasińska * and Andrzej Skrzypczyk \\ Department of Metal Science and Manufacturing Processes, Faculty of Mechatronics and Machine Engineering, \\ Kielce University of Technology, Al. Tysiąclecia Państwa Polskiego 7, 25-314 Kielce, Poland; tmaask@tu.kielce.pl \\ * Correspondence: kasinska@tu.kielce.pl; Tel.: +48-413-424-476
}

Received: 28 November 2017; Accepted: 1 February 2018; Published: 7 February 2018

\begin{abstract}
The paper reports the three-point bending test results of welded joints. The joints were made of chromium-molybdenum cast steel designed for the use at elevated temperatures. TIG (tungsten inert gas) welding technique was used. The fracture energy for particular joint zones and the stretch zone width (SZW) under the notch bottom were determined in a qualitative fracture toughness assessment. Fracture surface morphology was analyzed. The stretch zone measurement indicated a qualitative relationship between its width and the values of fracture energy. The results confirmed the influence of the modification on the character of fracture and the portions of brittle and ductile fracture in particular areas of welded joints.
\end{abstract}

Keywords: high temperature; fracture energy; morphology of fracture; TIG welding; rare earth metals

\section{Introduction}

G15CrMo5-5 cast steel is designed for use at elevated temperatures (up to $500^{\circ} \mathrm{C}$ ) and under high pressure in steam turbine valve chambers, valve bodies, or sealing rings of high-pressure vessels often exposed to abrasive wear [1,2]. Steel castings are typically welded to build up larger parts. Considering the operating conditions of cast steel products, adequate welding technologies for joint fabrication and repair-especially in power plants—need to be used [3]. The properties of the joints must match those of the parent material (cast steel).

Growing severity of the conditions under which cast steels operate has entailed considerable developments in joining and welding [3-6], including the invention of new technologies, e.g., friction stir welding [7-10] and the design of improved, modified welding materials [11]. One such modification that has proved very successful is adding rare earth metals (REMs) to steel/cast steel for lowering oxygen and sulphur contents [12,13] and changing the microstructure and morphology of non-metallic inclusions [13-17]. Adding rare earth metals to steel improves its properties [18-27]. Most commonly, Ce is used alone or in combination with other elements. The production of steel and cast steel containing REMs is difficult and successful modification depends on a number of factors, including adequate deoxidation of the molten metal, the REMs' amount, type and the time the addition is made. Nevertheless, rare earth metals bring a number of benefits in steelmaking by influencing the steel microstructure (grain refinement, non-metallic inclusion modification) and by increasing the strength and corrosion properties and hardness of the steel [25-33].

\section{Materials and Methods}

The welded joints were made of G17CrMo5-5 cast steel (Table 1). Cast steel melting was done under industrial conditions in an induction furnace with a capacity of $2000 \mathrm{~kg}$. Two types of cast steel 
heats were made-non-modified and modified-with REMs in the form of mischmetal added into the molten metal (1.02 kg mischmetal/t). The mischmetal chemical composition was as follows: $49.8 \% \mathrm{Ce}$, $21.8 \% \mathrm{La}, 17.1 \% \mathrm{Nd}, 5.5 \% \mathrm{Pr}$, and $5.35 \%$ of the other REMs.

Table 1. Chemical composition (\% mass) of G17CrMo5-5 cast steel according to PN-EN-10213-2.

\begin{tabular}{ccccccccc}
\hline C & Si & Mn & Cr & Mo & Ni & Al & S & P \\
\hline 0.18 & 0.4 & 0.9 & 1.2 & 0.53 & 0.07 & 0.041 & 0.015 & 0.022 \\
\hline
\end{tabular}

The samples $\left(200 \times 30 \times 25 \mathrm{~mm}^{3}\right)$ were taken from the test ingots subjected to a full heat treatment, i.e., normalizing $\left(940^{\circ} \mathrm{C} / 1 \mathrm{~h} /\right.$ air $)$ and tempering $\left(710^{\circ} \mathrm{C} / 2 \mathrm{~h} /\right.$ air $)$, which provided the ferrite + bainite microstructure (Figure 1) [31]. Evaluated qualitatively, after the heat treatment these changes involved a significant reduction in the ferritic matrix grain size and the reduction of precipitation processes in the modified cast steel during tempering. The transmission electron microscopy showed changes in dislocation density in the steel with the addition of REMs [32]. The samples were etched with the $\mathrm{HNO}_{3}$ solution in $\mathrm{C}_{2} \mathrm{H}_{5} \mathrm{OH}$ and examined in a light microscope (LM). The introduction of mischmetal to cast steel increased cast steel Charpy impact toughness (with a V notch), keeping plastic properties unchanged (Table 2) [31]. The favorable effect of the modifications on the material under lower service temperatures was already confirmed and the cast steel was subjected to lower temperature toughness tests to ASTM E 1820-17 [34] on the three-point bend specimens at temperatures ranging from $+20{ }^{\circ} \mathrm{C}$ to $-60{ }^{\circ} \mathrm{C}$ for unmodified cast steel and to $-80{ }^{\circ} \mathrm{C}$ for the cast steel with the rare earth metal addition. The $K_{\mathrm{JC}}$ fracture toughness values (Figure 2 ) and the brittle fracture transition temperature $T_{\mathrm{Q}}$, which was $-51.2{ }^{\circ} \mathrm{C}$ for the modified and $1.1{ }^{\circ} \mathrm{C}$ for the non-modified cast steel [35], were determined. The region of the ingot from which the test samples were taken, as well as the nature of the cast material, might be responsible for the scatter in the results.

The critical values of fracture toughness, $K_{\mathrm{JC}}$, were determined on single edge notched bend (SENB) specimens, precracked (initial crack length $\left(a_{0}\right)$ ) by fatigue. The dimensions of the specimens were $B=12 \mathrm{~mm}$ and $W=24 \mathrm{~mm}$ (Figure 3 ). The support span was $S=4 W$ with a notch relative length of $a / W \approx 0.5$ ( $a / W$-normalized crack size; $a$-crack length). The MTS $250 \mathrm{kN}$ testing system allowed the automatic recording of crack opening displacement measurement $\left(\delta_{\mathrm{M}}\right)$, applied load $(P)$ and the displacement at the load application point $(\Delta U)$. The crack extension was measured with a crack tip opening displacement (CTOD) extensometer and the displacement at the point of force application was also measured.

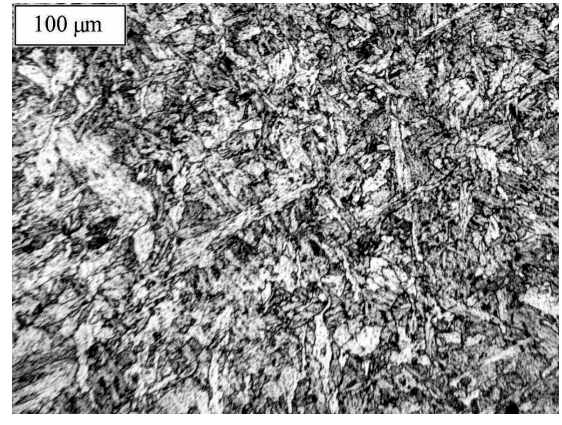

(a)

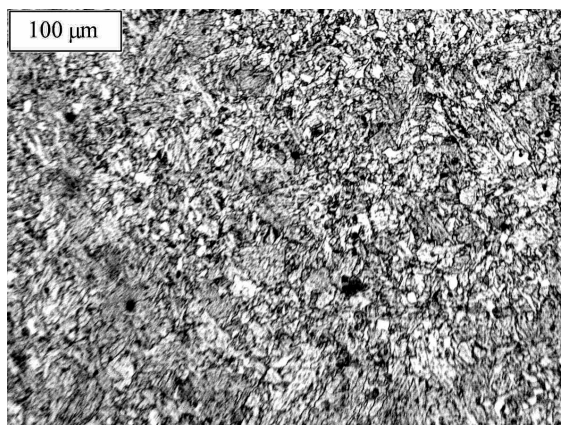

(b)

Figure 1. Microstructure of G17CrM05-5: (a) non-modified cast steel; (b) cast steel with REMs, LM, etched with $\mathrm{HNO}_{3}$ solution in $\mathrm{C}_{2} \mathrm{H}_{5} \mathrm{OH}$. 
Table 2. Mechanical properties of G17CrMo5-5 cast steel.

\begin{tabular}{cccccc}
\hline G17CrMo5-5 & $\begin{array}{c}\text { Yield Strength, } \\
\mathbf{M P a}\end{array}$ & $\begin{array}{c}\text { Tensile Strength, } \\
\mathbf{M P a}\end{array}$ & $\begin{array}{c}\text { Elongation, } \\
\mathbf{\%}\end{array}$ & $\begin{array}{c}\text { Necking, } \\
\mathbf{\%}\end{array}$ & $\begin{array}{c}\text { Impact Strength, } \\
\mathbf{J} / \mathbf{c m}^{\mathbf{2}}\end{array}$ \\
\hline Without REM addition & 507.4 & 661 & 20.08 & 63.6 & 30 \\
With REM addition & 551.4 & 685.2 & 19.92 & 62.4 & 99 \\
\hline
\end{tabular}

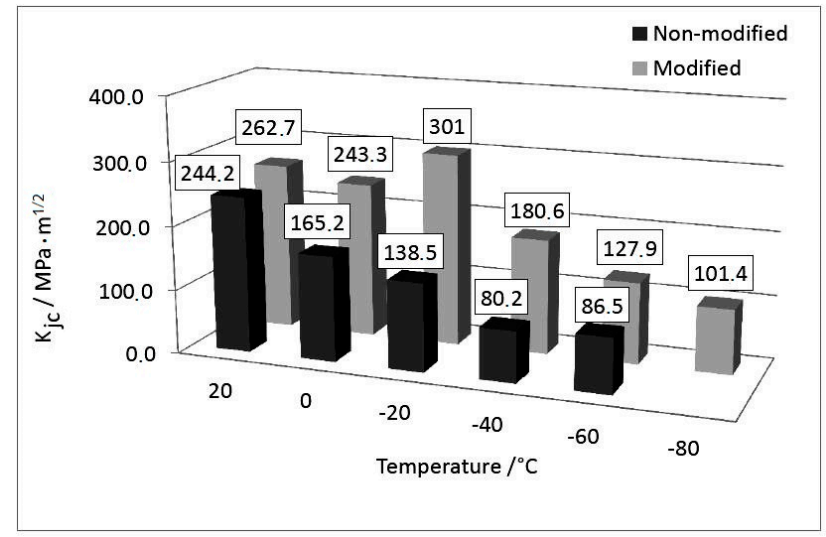

Figure 2. G17CrMo5-5 fracture toughness diagram.

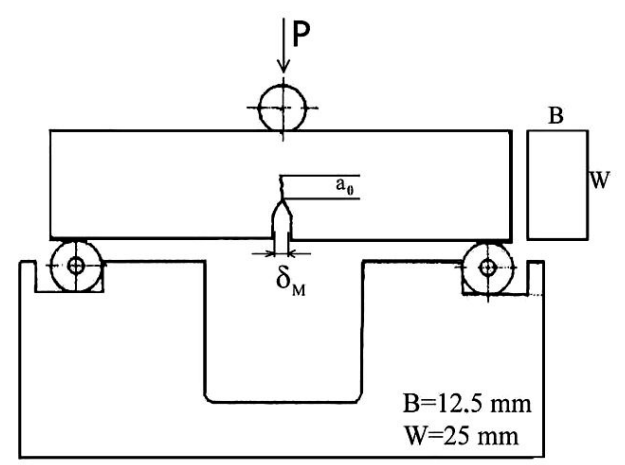

Figure 3. General diagram of the specimen loading in a three-point bending test.

The authors used the potential change method to record signal potential, load values, and specimen deflection. This enabled calculating the $J$ integral, the crack opening length, and then $J_{\text {IC }}$ ratio used for calculation of the $K_{\mathrm{JC}}$ stress intensity factor. The amount of energy released from the specimen was used to calculate the $J$ integral from:

$$
J=\frac{\eta A}{b_{0} B_{\mathrm{N}}}
$$

where:

$\eta$-for a three-point bend specimen $\eta=2$,

$b_{0}$-the initial length of un-cracked segment at the crack opening front $\left(b_{0}=W-a_{0}\right)$,

$B_{\mathrm{N}}$-specimen thickness,

$A$-area under the load-plastic displacement curve.

The critical value of $J_{\text {IC }}$ integral was determined according to the $J$-integral vs. crack extension graph in Figure 4 [31]. The critical value of $J$ integral is the intersection point of the $J-\Delta a$ dependence curve (denoted by the black line in Figure 4 ) and the straight line (denoted by the blue line in Figure 4) led from point 0.2 on the axis inclined to the $\Delta a$ axis at the angle whose tangent is (yield strength $\left(\sigma_{\mathrm{y}}\right)+$ tensile strength $\left.\left(\sigma_{\mathrm{UT}}\right)\right)$. 


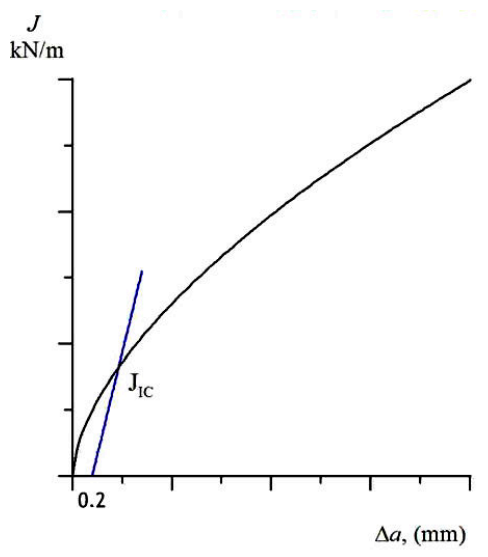

Figure 4. Example graph of $J_{\text {IC }}$ critical value.

The specimens were tested in the temperature range from $-80{ }^{\circ} \mathrm{C}$ to $20^{\circ} \mathrm{C}$ on a MTS-250 testing machine equipped with an automated control and data recording system. Low temperatures were obtained in a thermal chamber in the environment of liquid nitrogen vapours. In that temperature range, brittle, ductile, and mixed fracture mechanisms were observed. Fracture toughness was determined using the critical value of the $J$ integral, $J_{\mathrm{IC}}$, in accordance with ASTM standards $[34,36]$.

The $J_{\text {IC }}$ critical values were converted to the stress intensity factor (SIF) units, $K_{\mathrm{JC}}$, by the formula:

$$
K_{\mathrm{JC}}=\sqrt{J_{\mathrm{IC}} E /\left(1-v^{2}\right)}
$$

where $J_{\text {IC }}$ is the $J$-integral critical value, $E$ is Young's modulus, and $v$ is Poisson's ratio.

Both the reference temperature in the brittle-to-ductile transition region, $T_{\mathrm{Q}}$, and the master curves were determined in accordance with the recommendations by Wallin, Gao, Dodds, and Ruggeri et al. [37-41], and the procedures set forth in ASTM E1921-10 [42] and in FITNET [43]. The reference temperature, $T_{\mathrm{Q}}$, corresponds to the value of fracture toughness equal to $K_{\mathrm{JC}}=100 \mathrm{MPa} \cdot \mathrm{m}^{1 / 2}$. This procedure is applied to ferritic steels with yield strength in the range $285 \leq \sigma_{\mathrm{y}} \leq 825 \mathrm{MPa}$. Experimentally measured fracture toughness is obtained either at one or at several temperatures. According to the procedure, fracture toughness is determined on specimens with $B=25 \mathrm{~mm}$. In the case where the specimen thickness is less than $25 \mathrm{~mm}$ or exceeds this value, the fracture toughness should be corrected using the formula [43]:

$$
K_{\mathrm{mat}}=K_{\min }+\left(K_{\mathrm{JC}}-K_{\min }\right)\left(\frac{B}{25}\right)^{0.25}
$$

where $K_{\min }$ is a minimum value of fracture toughness, which is assumed to be $K_{\min }=20 \mathrm{MPa} \cdot \mathrm{m}^{1 / 2}[42,43]$. In the case when the fracture toughness is measured at several different temperatures, the brittle-toductile transition temperature, $T_{\mathrm{Q}}$, can be calculated from the equation:

$$
\sum_{i=1}^{n} \frac{\delta_{i} \exp \left(0.091\left(T_{i}-T_{\mathrm{Q}}\right)\right)}{\left(11+77 \exp \left(0.091\left(T_{i}-T_{\mathrm{Q}}\right)\right)\right)}=\sum_{i=1}^{n} \frac{\left(K_{\mathrm{JC} i}-20\right)^{4} \exp \left(0.091\left(T_{i}-T_{\mathrm{Q}}\right)\right)}{\left(11+77 \exp \left(0.019\left(T_{i}-T_{\mathrm{Q}}\right)\right)\right)^{5}}
$$

where $K_{\mathrm{JC} i}$ is the $i$-th value of fracture toughness determined at the temperature $T_{i} ; n$ is a number of tested specimens; $\delta_{i}$ equals 1 , then $K_{\mathrm{JC} i}<K_{\mathrm{cenz}}$, or 0 , when the inequality is in the opposite direction.

The censored value $K_{\text {cenz }}$ is calculated from the formula:

$$
K_{\mathrm{cenz}}=\left(E b_{0} \sigma_{\mathrm{y}} / 30\right)^{1 / 2}
$$

where $b_{0}$ is the un-cracked ligament width of the specimen. 
If the value of the brittle-to-ductile transition temperature, $T_{\mathrm{Q}}$, is known, the data set by the relationship $K_{\text {mat }}=f(T)$, called a "master curve", is obtained [42,43]:

$$
K_{\mathrm{mat}}=30+70 \exp \left(0.019\left(T-T_{\mathrm{Q}}\right)\right)
$$

\section{Test Joints Welding}

Samples made of G17CrMo5-5 cast steel were used to make flat test butt joints measuring $200 \times 84 \times 12 \mathrm{~mm}^{3}$. TIG welding technique was used. Welding consumables included LNT/LNM-19 solid welding wire [44] and argon as shielding gas [45]. The chemical composition of the welding wire was as follows: $0.10 \%$ C, $0.5 \% \mathrm{Si}, 1.0 \% \mathrm{Mn}, 1.2 \% \mathrm{Cr}, 0.5 \% \mathrm{Mo}$. Double-sided multilayer TIG welding was performed. Table 3 summarizes the basic technological parameters of welded joints fabrication. Test joints were welded in the flat position (PA). The heat treatment procedures accompanying the welding are shown in Figure 5.

Table 3. Technological parameters of test joints fabrication.

\begin{tabular}{ccccccc}
\hline Run No. & $\begin{array}{c}\text { Welding } \\
\text { Method [46] }\end{array}$ & $\begin{array}{c}\text { Filler Wire } \\
\text { Diameter, } \mathbf{~ m m}\end{array}$ & $\begin{array}{c}\text { Current, } \\
\mathbf{A}\end{array}$ & $\begin{array}{c}\text { Arc Voltage, } \\
\text { V }\end{array}$ & $\begin{array}{c}\text { Welding Speed, } \\
\text { cm/min }\end{array}$ & $\begin{array}{c}\text { Shielding Gas } \\
\text { Flow, L/min }\end{array}$ \\
\hline 1,3 & 141 & $\phi=2.0$ & 100 & 11.3 & $25-30$ & $8.0-10.0$ \\
2,4 & 141 & $\phi=2.4$ & 120 & 11.9 & $20-25$ & 12.0 \\
$5-10$ & 141 & $\phi=2.4$ & 130 & 13.2 & $20-25$ & 12.0 \\
\hline \multicolumn{7}{c}{ Pre-heating temperature: $100^{\circ} \mathrm{C}$, inter-pass temperature: $200-230^{\circ} \mathrm{C}$, annealing: $710^{\circ} \mathrm{C}}$. \\
\hline
\end{tabular}

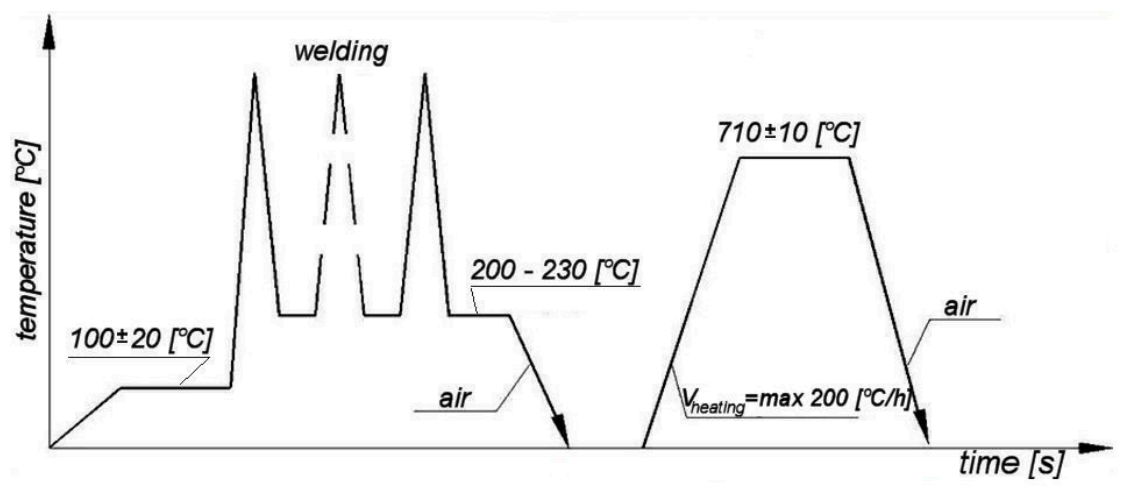

Figure 5. Diagram of heat treatment procedures used for welding G17CrMo5-5 cast steel.

\section{Results}

\section{Three-Point Bending Test}

The test samples were taken from the joints to determine fracture toughness. The samples from the non-modified cast steel were designated as a series and those taken from the REMs modified cast steel as B series. Three samples were provided for each series. The test was performed on three-point bend flat samples according to ASTM E1820-09 [36] in an MTS $250 \mathrm{kN}$ test machine with automatic measurement of the gap $\left(\delta_{\mathrm{M}}\right)$, force $(P)$, and the displacement at the load application point $(\Delta U)$. The crack extension was measured with a crack tip opening displacement (CTOD) extensometer. Pre-cracked and notched samples were used. The initial crack length $\left(a_{0}\right)$ was derived by subjecting the samples to fatigue bending at constant amplitude. The specimens prepared in this way were subjected to bending using a monotonically increasing load. The procedure was carried out in the same way as that for the brittle transition temperature $T_{\mathrm{Q}}$ (Section 2). The fracture toughness $K_{\mathrm{JC}}$ of the fabricated welded joints could not be explicitly determined due to irregular gap front. Thus, not all normative requirements were met. The energy of cracking was determined according to the diagram 
in Figure 6. The fracture energy was calculated by separating the energy from the area under the graph (total energy) by the product $b_{0}$ and $B$ (where $b_{0}$-the unprocessed part of the sample, $B$ - the effective thickness of the sample). The thicknesses were measured as displacement $U_{\text {ext }}$ using an extensometer.

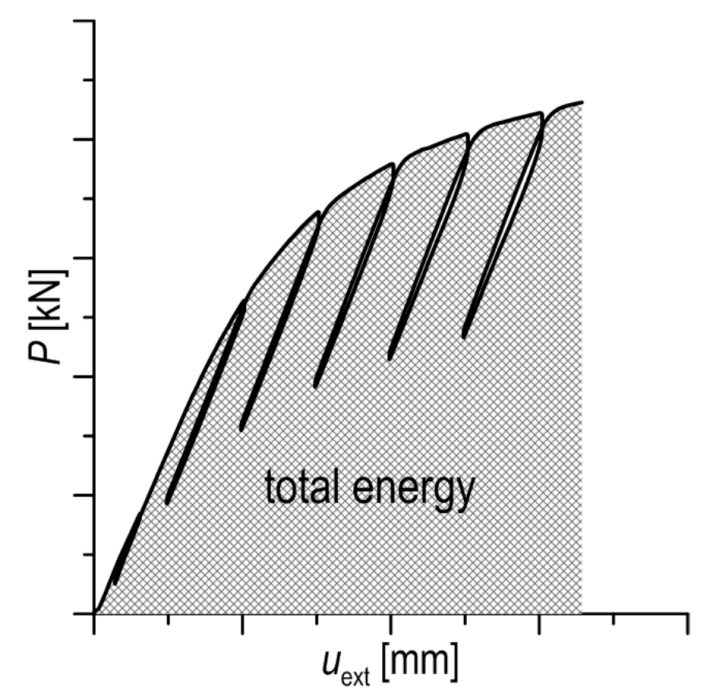

Figure 6. Scheme of fracture energy determination.

The welded joints (series A and B) were fabricated as double-sided multilayer joints with the edge in the shape of the letter " $X$ ". The fatigue crack was initiated in the weld (A1, B1) and in the heat-affected zone (HAZ) (A2, A3, B2, B3). The fracture energy was determined for each joint zone (Table 4, Figures 7 and 8 ) at the moment of fracture initiation.

Table 4. Fracture energy of each joint zone.

\begin{tabular}{ccc}
\hline Joint No. & Area & Fracture Energy, $\mathbf{k J} / \mathbf{m m}^{\mathbf{2}}$ \\
\hline A1 & weld & 87 \\
A2 & weld + HAZ & 135 \\
A3 & HAZ & 275 \\
B1 & weld & 67 \\
B2 & weld + HAZ + parent material & 212 \\
B3 & HAZ & 433 \\
\hline
\end{tabular}

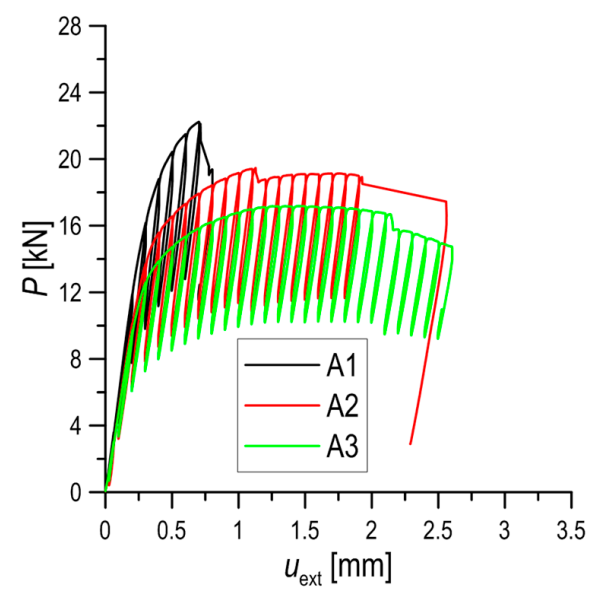

Figure 7. Force-displacement diagram for welded joint tests for unmodified cast steel (A series). 


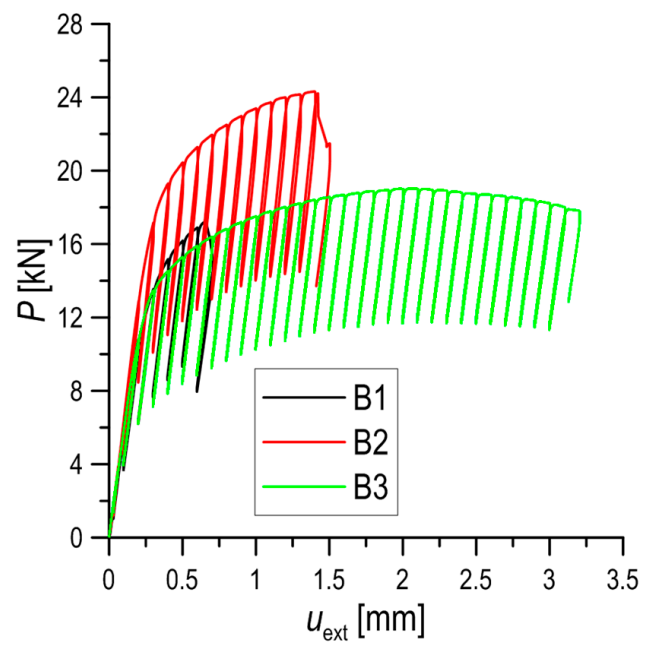

Figure 8. Force-displacement diagram for welded joint tests for unmodified cast steel (B series).

The specimens on the cross-section were etched in $4 \% \mathrm{HNO}_{3}$ solution in $\mathrm{C}_{2} \mathrm{H}_{5} \mathrm{OH}$. Macroscopic cross sectional observations of the resulting cracks allowed determining the joint zones where the crack propagated.

Macroscopic observations of the resulting fracture surfaces (Figure 9) were analyzed for fracture energy values. In samples A1 and B1, a crack developed in the joint and in both cases a high proportion of brittle fracture was observed. In sample A2, the crack developed in the joint and propagated across the HAZ causing an increase in fracture energy. Similarly, the crack in sample B2 ran across the joint and HAZ and, additionally, in the parent material. In both cases (A2 and B2) the increase in the fracture energy value was significantly higher in the modified cast steel joint. In samples A3 and B3, cracking developed across the HAZ. The highest proportion of ductile fracture was observed for A3 and B3. In both samples, there was an increase in fracture energy, mostly in the modified cast steel.

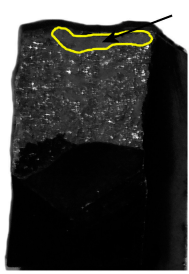

A1

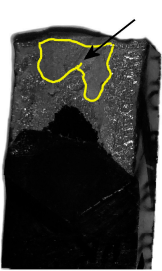

A2

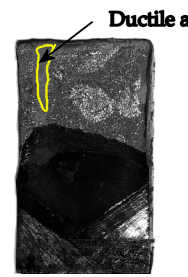

A3

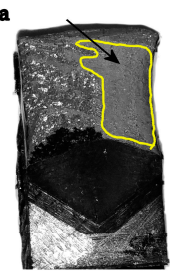

B1

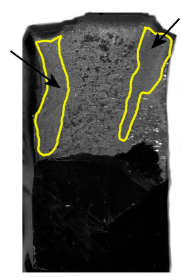

B2

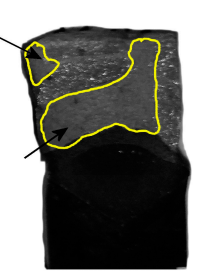

B3

Figure 9. Overview of three-point bend fracture surfaces.

\section{Discussion}

The average value of fracture energy for each A and B series was not determined. Each sample was analyzed individually due to different crack propagation through the various areas of the welded joint (weld, HAZ, and parent material).

All fracture surfaces were subjected to fractographic analysis in the scanning electron microscope. The stretch zone width (SZW; areas included by the 2 solid lines in Figure 10), a criterion for the qualitative assessment of fracture toughness, was measured under the bottom of the notch (Figure 10) between the fatigue pre crack zone and the crack extension zone. The stretch zone ("threshold") is formed at the moment of rapid failure of the material between the fatigue zone of the fracture and the residual fracture. A wider stretch zone indicates higher fracture toughness, as confirmed in this study. Many researchers have reported a correlation between the width of the stretch zone and the fracture 
toughness. The $J$ integral at the moment of crack initiation, $J_{i}$, based on the measurement of the stretch zone width can be calculated according to several procedures described in the literature [47-54].

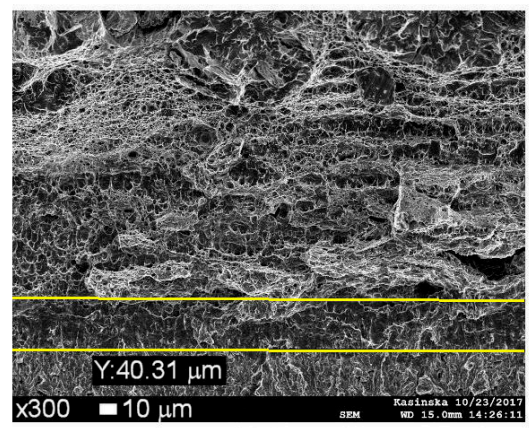

A 1

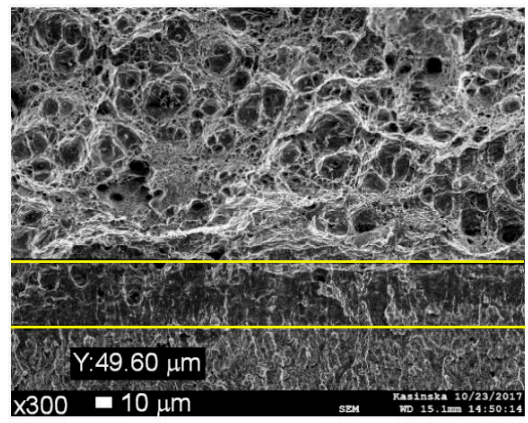

A 2

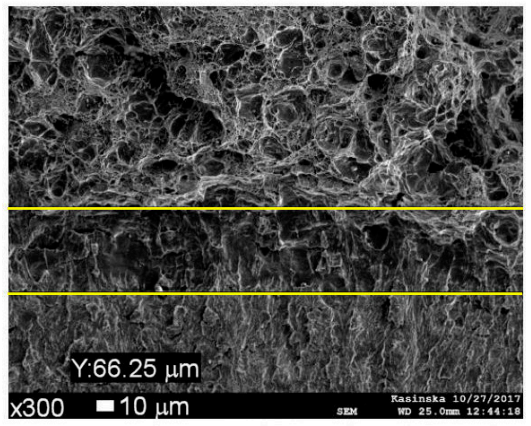

A 3

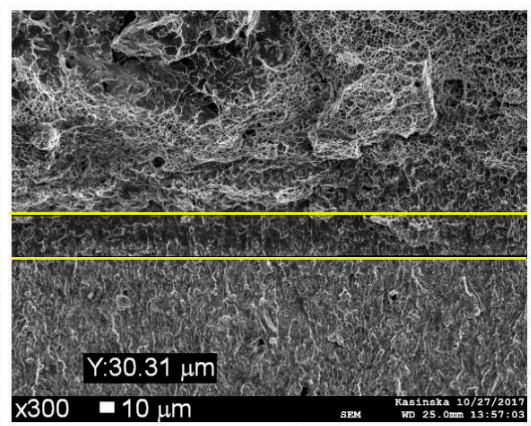

B 1

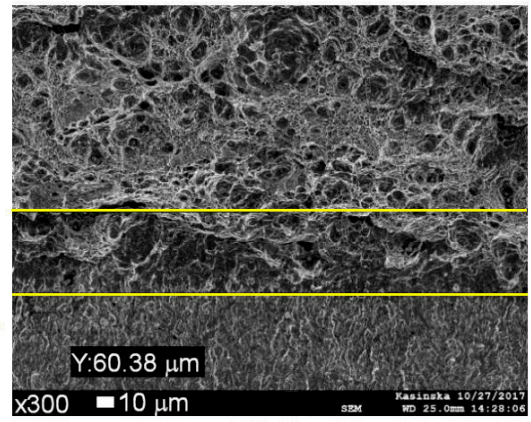

B 2

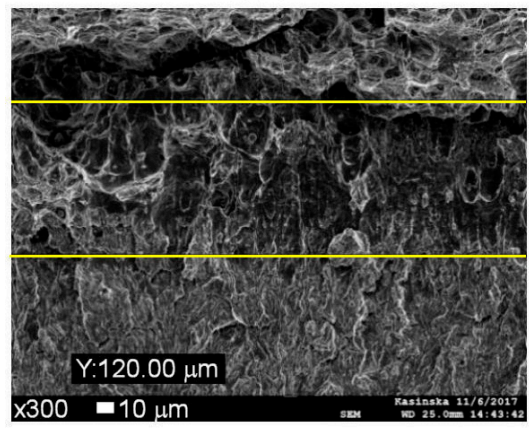

B 3

Figure 10. Images of fracture surfaces under the notch bottom with visible stretch zones.

For specimens A1, A2, and A3, the width was 40,49, and $66 \mu \mathrm{m}$, respectively whereas for specimens B1, B2, and B3, it was 30, 64, and $120 \mu \mathrm{m}$. In the welded joints made of modified cast steel, the stretch zone was wider than that of unmodified cast steel. This applies to cracks in the HAZ and parent material. The differences between samples A1 and B1 result from the crack propagation area, i.e., the weld.

Observations of A1, A2, and A3 fracture surfaces and B1, B2, and B3 specimens indicate brittle fracture character (Figures 8-10), with areas of ductile fracture (Figures 11-13, lower section of the photographs). Depending on the areas in which the crack propagated, a different proportion of ductile fracture to brittle fracture is observed. Large transcrystalline cracks are seen mostly in the B1 weld, which explains lower fracture energy in this sample. Ductile fracture areas are visible in both variants. Microscopic images of the A2 and B2 samples show brittle nature of the fracture with numerous steps forming "river basins" and "river patterns". In the case of sample B2, the fracture surface is much more developed, which indicates fine grained structure. More ductile fracture strips with smaller dimples around precipitates are visible in the brittle fracture area. Grain refinement and the change in inclusions 
morphology result also from the presence of mischmetal in the cast steel. Few transcrystalline cracks can be seen in A3 and B3 brittle fracture areas (Figure 13). In the B3 modified steel sample, as in B2, the morphology of the fracture is more developed and the ductile cracking bands are much more common than in the cast steel samples without the REMs addition. Compared with A3, the proportion of ductile fracture is much higher, reaching $50 \%$.
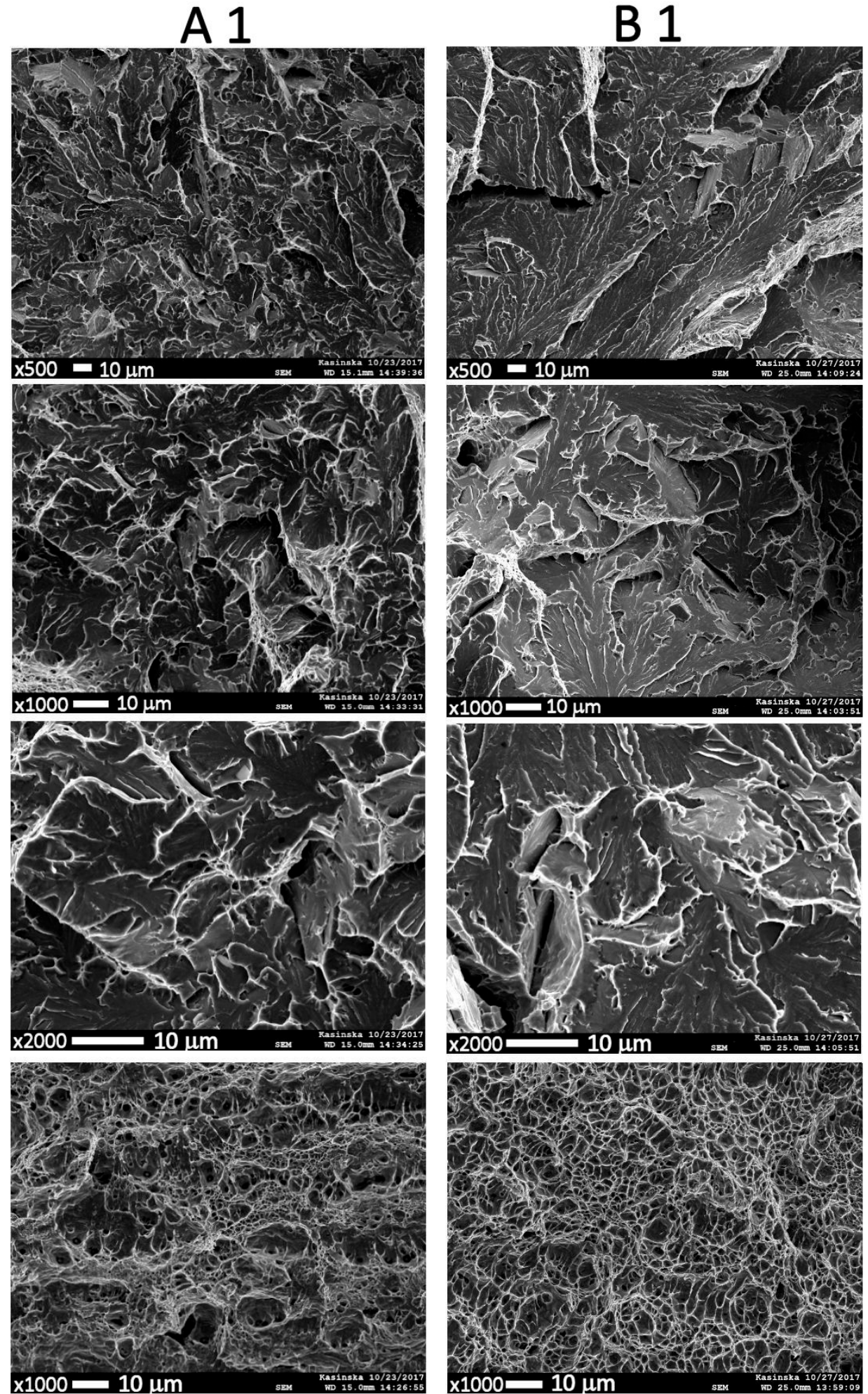

Figure 11. Morphology of A1 and B1 fracture surfaces. 
A 2
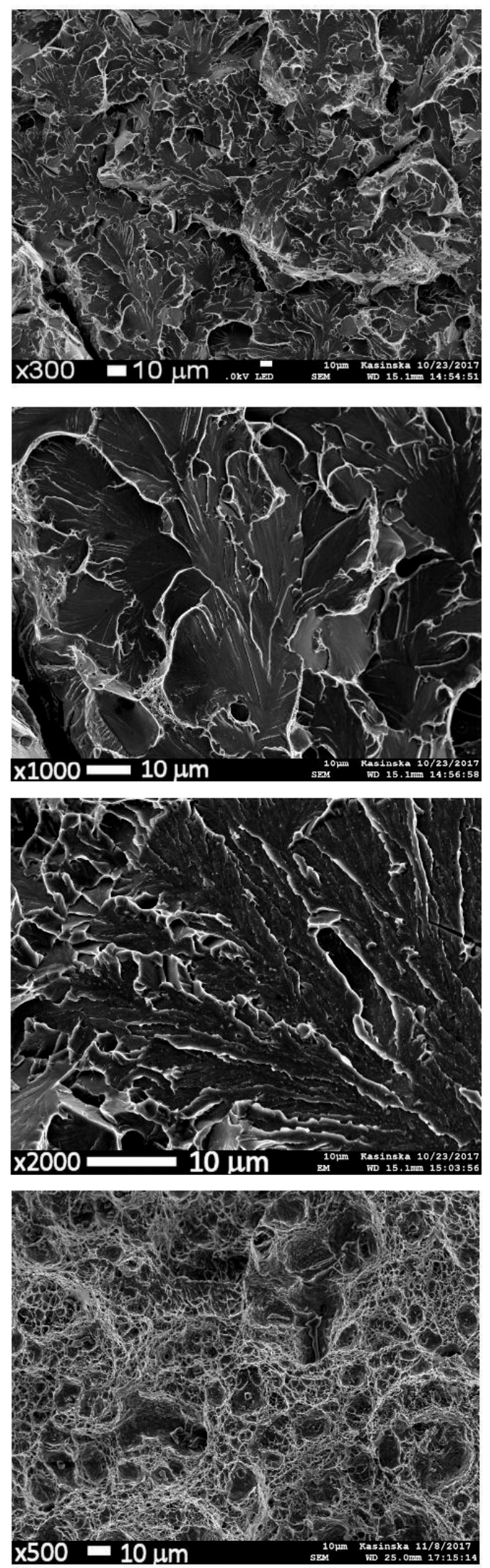

B 2
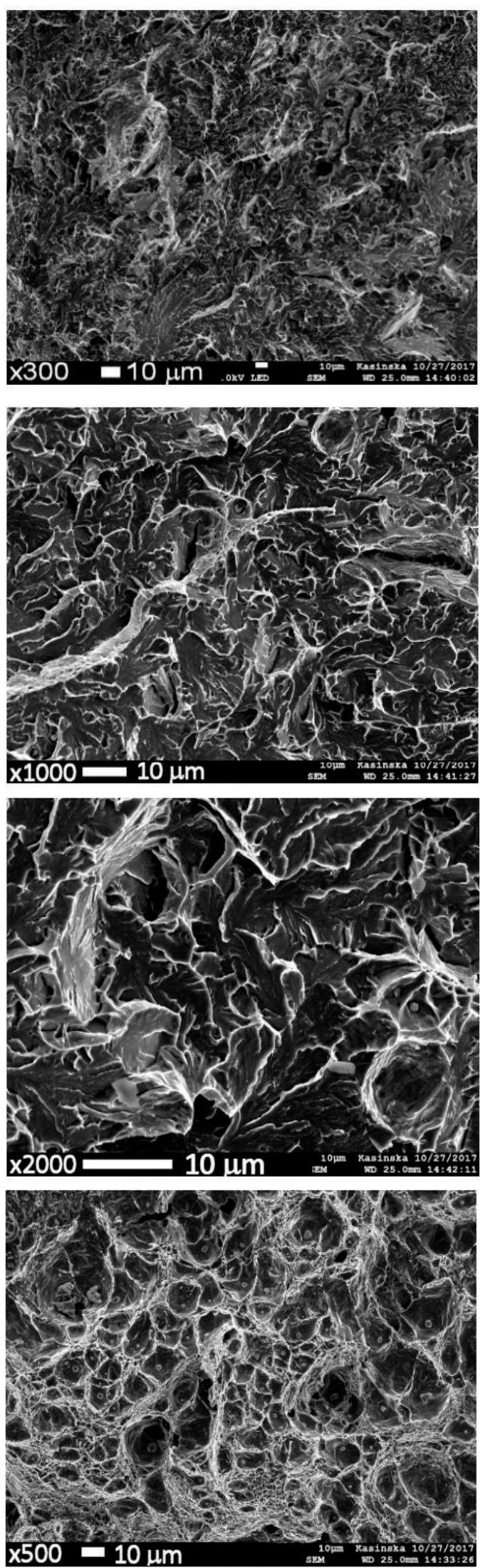

Figure 12. Morphology of A2 and B2 fracture surfaces. 


\section{A 3}

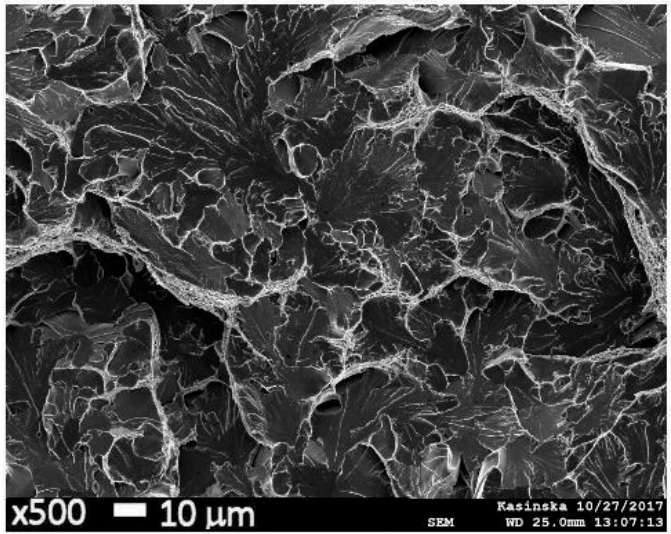

\section{B 3}
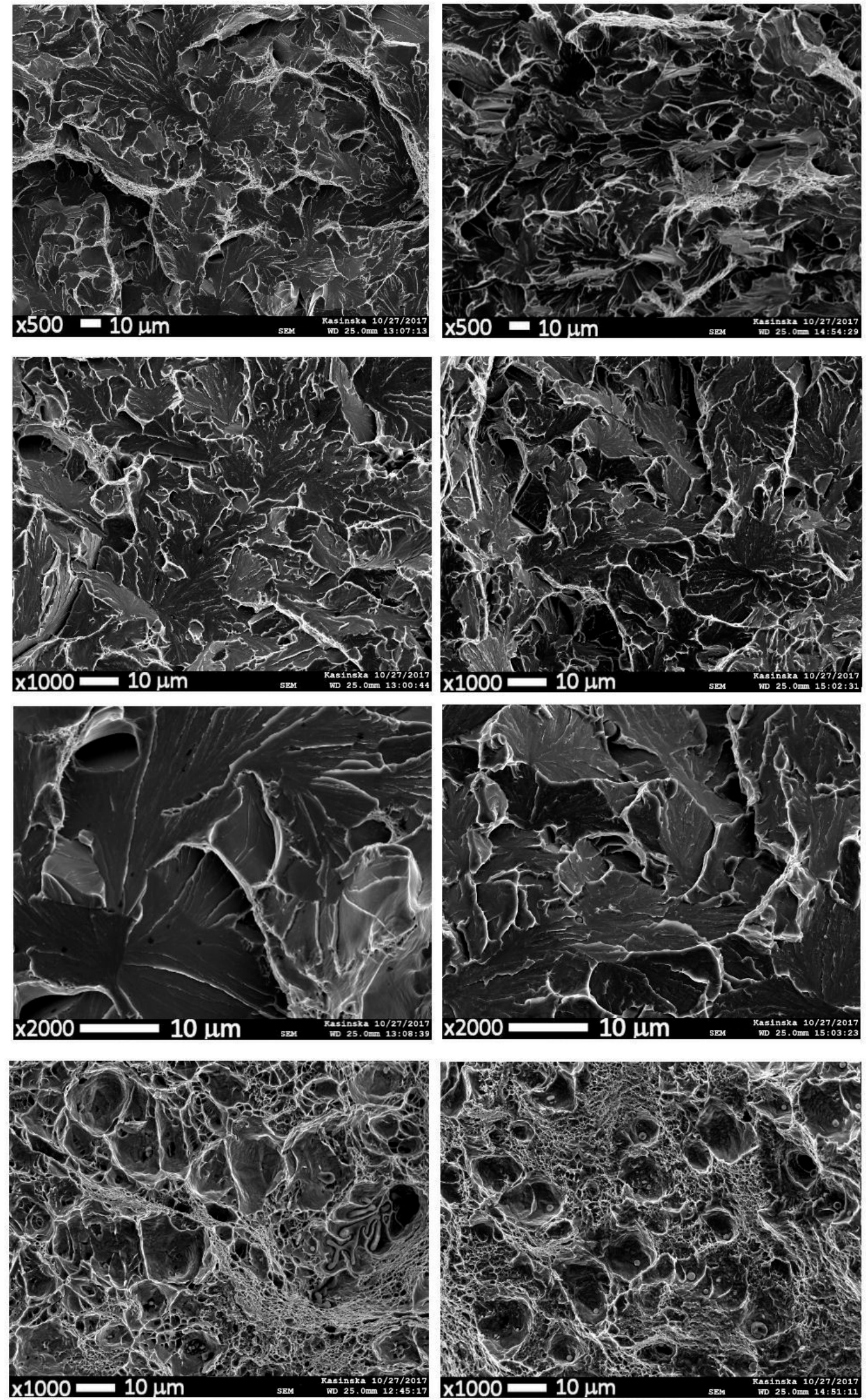

Figure 13. Morphology of A3 and B3 fracture surfaces. 
The inclusions in the modified cast steel are characterized by a much larger dispersion (Figure 14) and morphology and size changes (Figures 15 and 16). The inclusions formed during the modification process and were mostly oxysulphides (Figure 17) [32,33]. The REMs addition in the liquid steel caused the inclusions to take on a globular shape and be more evenly distributed in the matrix. No clusters of oxides and sulphides were observed as was the case with unmodified cast steel.

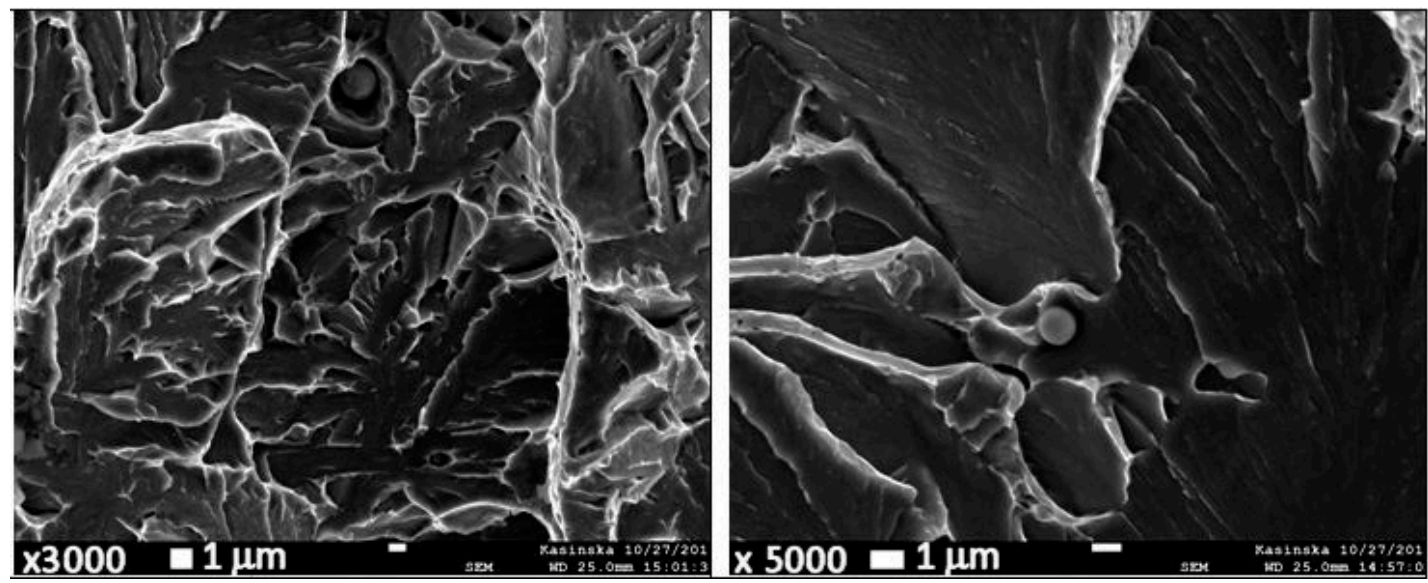

Figure 14. REMs oxysulphides on fracture surfaces of the Charpy-V impact test.

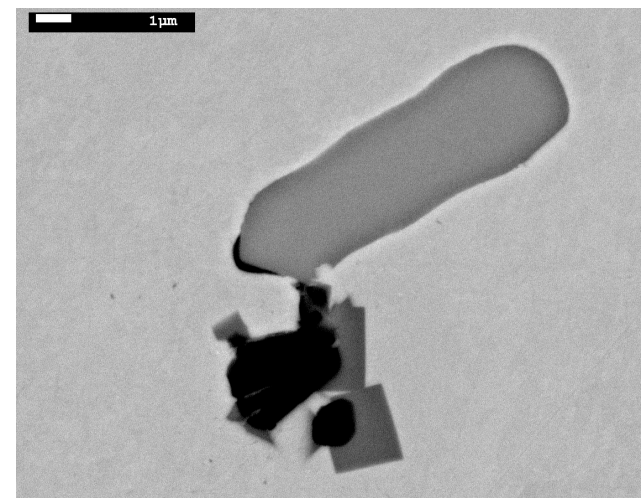

(a)

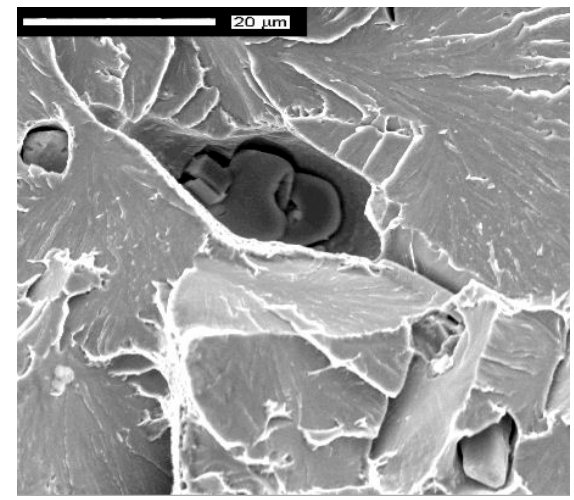

(b)

Figure 15. Nonmetallic inclusions in non-modified cast steels: (a) metallographic sample; (b) on the fracture surface of the Charpy-V impact test.

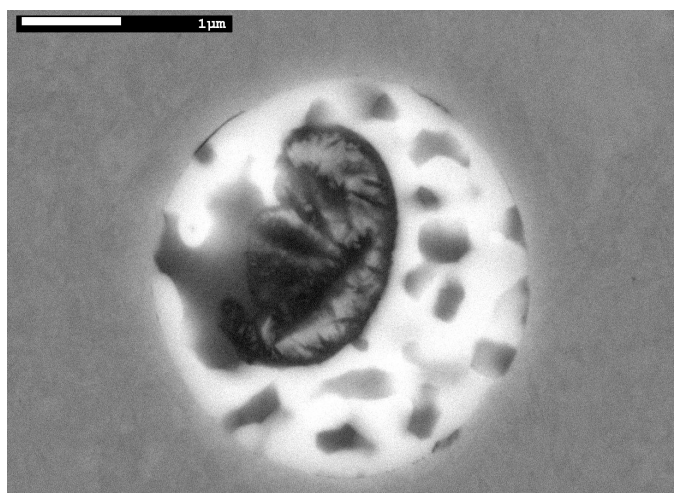

(a)

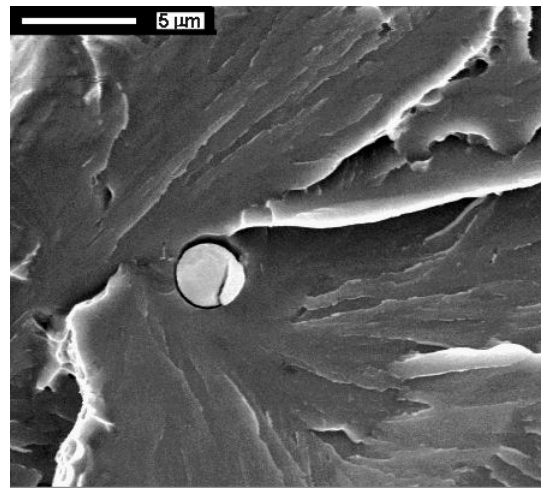

(b)

Figure 16. Non-metallic inclusions in modified cast steels: (a) metallographic sample; (b) on the fracture surface of the Charpy-V impact test. 


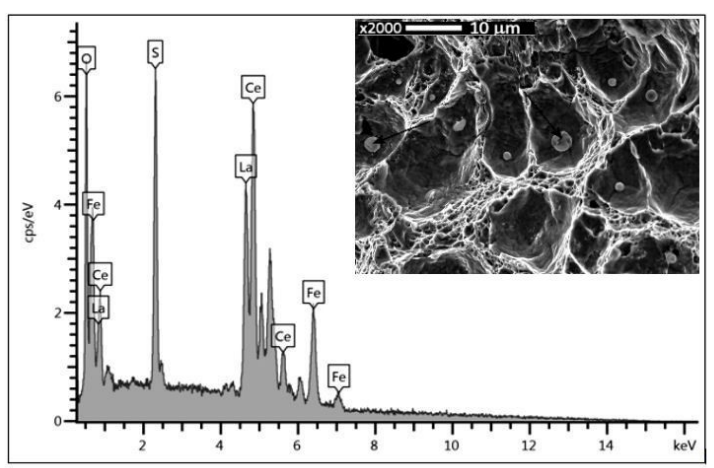

Figure 17. X-ray spectrum of inclusions on fracture surfaces.

\section{Conclusions}

1. Modification of G17CrMo5-5 cast steel with mischmetal seems to have an advantageous effect on the fracture energy of the weld joints.

2. The stretch zone measurement indicates a qualitative relationship between its width and the values of fracture energy. The widths in the B-series samples were noticeably larger than those in the A-series samples.

3. The fractographic analysis of the fractures from the weld and HAZ confirmed the influence of modification on their character, in particular in the case of HAZ where a significant development of the fracture surface was observed. For specimens A1, A2, and A3, the stretch zone lengths are 40, 49, and $66 \mu \mathrm{m}$, respectively whereas for specimens B1, B2, and B3, they are 30, 64, and $120 \mu \mathrm{m}$. The introduction of Ce mixture into the cast steel refined the grain, changed the morphology of non-metallic inclusions, and increased the dispersion of the inclusions.

4. In order to determine the fracture energy for particular areas of the welded joint, it is suggested to prepare half Y-shaped welding edges. Such preparation for research purposes can ensure that the crack propagates only through the homogeneous joint area, i.e., HAZ or weld, and this will allow determining the $K_{\mathrm{JC}}$.

5. The results should be considered as a qualitative relationship between particular areas of the A and B series joints.

Acknowledgments: The authors gratefully acknowledge the financial support provided by the Ministry of Science and Higher Educations for the project number 01.0.10.00/2.01.01.01.0040 MNSP.MKMT.18.003.

Author Contributions: Justyna Kasińska carried out the melting process, SEM investigations, analyzed, discussed the data, and wrote the manuscript. Andrzej Skrzypczyk carried out the welding process, analyzed the mechanical properties of welded joints, and supervised the project, discussed the data, and edited the manuscript.

Conflicts of Interest: The authors declare no conflict of interest.

\section{References}

1. Mańkowski, P.; Kalandyk, B.; Zapała, R. Effect of melting technology on the properties of G17CrMo5-5 steel for cast turbines. Arch. Foundry Eng. 2010, 10, 133-136.

2. Błacha, S.; Weglowski, M.S.; Dymek, S.; Kopuściański, M. Microstructural characterization and mechanical properties of electron beam welded joint of high strength steel grade S690QL. Arch. Metall. Mater. 2016, 61, 1193-1200. [CrossRef]

3. Viswanathan, R.; Henry, J.F.; Tanzosh, T.; Stanko, G.; Shingledecker, J.; Vitalis, B.; Purgert, R.U.S. Program on materials technology for ultra-supercritical coal power plants. J. Mater. Eng. Perform. 2005, 14, 281-292. [CrossRef]

4. Viswanathan, R.; Bakker, W. Materials for ultrasupercritical coal power plants-Boiler materials: Part 1. J. Mater. Eng. Perform. 2001, 10, 81-95. [CrossRef] 
5. Yamashita, Y.; Kawano, T.; Mann, K. Underwater laser welding by 4 kW CW YAG Laser. J. Nucl. Sci. Technol. 2001, 38, 891-895. [CrossRef]

6. Vaillant, J.C.; Vandenberghe, B.; Hahn, B.; Heuser, H.; Jochum, C. T/P23, 24, 911 and 92: New grades for advanced coal-fired power plants-Properties and experience. Int. J. Press. Vessel. Pip. 2008, 85, 38-46. [CrossRef]

7. Nishida, H.; Ogura, T.; Hatano, R.; Kurashima, H.; Fujimoto, M.; Hirose, A. Fracture toughness and fatigue crack behaviour of A3003/SUS304 lap friction stir welded joints. Weld. Int. 2016, 31, 268-277. [CrossRef]

8. Carlone, P.; Citarella, R.; Sonne, M.R.; Hattel, J.H. Multiple crack growth prediction in AA2024-T3 friction stir welded joints, including manufacturing effects. Int. J. Fatigue 2016, 90, 69-77. [CrossRef]

9. Carlone, P.; Citarella, R.; Lepore, M.; Palazzo, G.S. A FEM-DBEM investigation of the influence of process parameters on crack growth in aluminum friction stir welded butt joints. Int. J. Mater. Form. 2014, 8, 591-599. [CrossRef]

10. Yang, B.; Yan, J.; Sutton, M.A.; Reynolds, A.P. Banded microstructure in AA2024-T351 and AA2524-T351 aluminum friction stir welds Part I. Metallurgical studies. Mater. Sci. Eng. A 2004, 364, 55-65. [CrossRef]

11. Zou, J.; Zhao, Q.; Chen, Z. Surface modified long-life electrode for resistance spot welding of Zn-coated steel. J. Mater. Process. Technol. 2009, 209, 4141-4146. [CrossRef]

12. Sorrentino, S. Welding technologies for ultra-supercritical power plant materials. In Materials for Ultra-Supercritical and Advanced Ultra-Supercritical Power Plants; Di Gianfresco, A., Ed.; Elsevier: Duxford, UK, 2017; pp. 247-319.

13. Waubdy, P.E. Rare earth addition to steel. Int. Met. Rev. 1978, 2, 74-99.

14. Adabavazeh, Z.; Hwang, W.S.; Su, Y.H. Effect of adding cerium on microstructure and morphology of Ce-based inclusions formed in low-carbonsteel. Sci. Rep. 2017, 7, 46503. [CrossRef] [PubMed]

15. Ha, H.; Park, C.; Kwon, H. Effects of misch metal on the formation of non-metallic inclusions and the associated resistance to pitting corrosion in 25\% Cr duplex stainless steels. Scr. Mater. 2006, 55, 991-994. [CrossRef]

16. Cai, Y.C.; Liu, R.P.; Wei, Y.H.; Cheng, Z.G. Influence of Y on microstructures and mechanical properties of high strength steel weld metal. Mater. Des. 2014, 62, 83-90. [CrossRef]

17. Ahn, J.H.; Jung, H.D.; Im, J.H.; Jung, K.H.; Moon, B.-M. Influence of the addition of gadolinium on the microstructure and mechanical properties of duplex stainless steel. Mater. Sci. Eng. A 2016, 658, $255-262$. [CrossRef]

18. Liu, H.; Fu, P.; Liu, H.; Sun, C.; Gao, J.; Li, D. Carbides evolution and tensile property of 4Cr5MoSiV1 die steel with rare earth addition. Metals 2017, 7, 436. [CrossRef]

19. Drapala, J.; Brozova, S.; Szurman, I.; Konecna, K.; Kosyiukova, G.; Vontorova, J.; Jonsta, P.; Sobotkova, K. Influence of selected rare earth metals on structural characteristics of 42CrMo4 steel. Metalurgija 2016, 55, 757-760.

20. Fu, H.; Xiao, Q.; Li, Y. A study of the microstructures and properties of Fe-V-W-Mo alloy modified by rare earth. Mater. Sci. Eng. A 2005, 395, 281-287. [CrossRef]

21. Gao, J.; Fu, P.; Liu, H.; Fu, P.; Li, D. Effects of rare earth on the microstructure and impact toughness of H13 steel. Metals 2015, 5, 383-394. [CrossRef]

22. Wang, M.; Mu, S.; Sun, F.; Wang, Y. Influence of rare earth elements on microstructure and mechanical properties of cast high-speed steel rolls. J. Rare Earth 2007, 25, 490-494. [CrossRef]

23. Hamidzadeh, M.A.; Meratian, M.; Saatchi, A. Effect of cerium and lanthanum on the microstructure and mechanical properties of AISI D2 tool steel. Mater. Sci. Eng. A 2013, 571, 193-198. [CrossRef]

24. Fu, H.; Xiao, Q.; Kuang, J.; Jiang, Z.; Xing, J. Effect of rare earth and titanium additions on the microstructures and properties of low carbon Fe-B cast steel. Mater. Sci. Eng. A 2007, 466, 160-165. [CrossRef]

25. Torkamani, H.; Raygan, S.; Mateo, C.G.; Rassizadehghani, J.; Vivas, J.; Palizdar, J.; San-Martin, D. The influence of La and Ce addition on inclusions modification in cast nobium microalloyed steels. Metals 2017, 7, 377. [CrossRef]

26. Tang, Z.; Zhang, H.; Wu, J. Influence of Re and Re-Ca addition on microstructure and mechanical properties of steel 35MnSiCrMoV. In Proceedings of the 2nd International Conference on Civil, Materials and Environmental Sciences, Phuket, Thailand, 20-21 December 2015.

27. Cosandey, F.; Li, D.; Sczerzenie, F.; Tien, J. The effect of cerium on high temperature tensile and creep behavior of a superalloy. Metall. Trans. A 1983, 14, 611-621. [CrossRef] 
28. Liu, C.; Huang, Y.; Jiang, M. Effects and mechanisms of RE on impact toughness and fracture toughness of clean heavy rail steel. J. Iron Steel Res. Int. 2011, 18, 52-58. [CrossRef]

29. Jeon, S.H.; Kim, S.T.; Choi, M.S.; Kim, J.S.; Kim, K.T.; Park, Y.S. Effects of cerium on the compositional variations in and around inclusions and the initiation and propagation of pitting corrosion in hyperduplex stainless steel. Corros. Sci. 2013, 75, 367-375. [CrossRef]

30. Skrzypczyk, A.; Kasińska, J.; Furmańczyk, P. Analysis of impact fractures of welded joints of G17CrMo5-5 cast steel. In Sympozjum Katedr i Zakładów Spawalnictwa "Nowoczesne Zastosowania Technologii Spawalniczych"; Jacek Górka, Komisja Odlewnictwa PAN: Istebna, Poland, 2017; pp. 291-298. (In Polish)

31. Gajewski, M.; Kasińska, J. Rare earth metals influence on mechanical properties and crack resistance of GP240GH and G17CrMo5-5 cast steels. Arch. Foundry Eng. 2009, 9, 37-44.

32. Kasińska, J. Influence of rare earth metals on microstructure and inclusions morphology G17CrMo5-5 cast steel. Arch. Metall. Mater. 2014, 59, 993-996. [CrossRef]

33. Gajewski, M.; Kasińska, J. Rare earth metals influence on morphology of non-metallic inclusions and mechanism of GP240GH and G17CrMo5-5cast steel cracking. Arch. Foundry Eng. 2009, 9, 45-52.

34. ASTM E 1820-17. Standard Test Method for J-Integral Characterization for Fracture Toughness; American Society for Testing and Materials (ASTM): West Conshohocken, PA, USA, 2017.

35. Dzioba, I.; Kasińska, J.; Pała, R. The influence of the rare earth metals modification on the fracture toughness of G17CrMo5-5 cast steel at low temperatures. Arch. Metall. Mater. 2015, 60, 773-777. [CrossRef]

36. ASTM E1820-09. Standard Test Method for Measurement of Fracture Toughness; American Society for Testing and Materials (ASTM): West Conshohocken, PA, USA, 2011; pp. 1070-1118.

37. Wallin, K. Master Curve Analysis of Ductile to Brittle Transition Region Fracture Toughness Round Robin Data (The Euro Fracture Toughness Curve); VTT Technical Document 367.58P; Technical Research Centre of Finland: Espoo, Finland, 1998.

38. Wallin, K. Recommendations for the application of fracture toughness data for structural integrity assessments. In Proceedings of the Joint IAEA/CSNI Specialists Meeting on Fracture Mechanics Verification by Large-Scale Testing, NUREG/CP-0131 (ORNL/TM-12413), Oak Ridge, TN, USA, 26-29 October 1993; pp. 465-494.

39. Wallin, K. The scatter in $K_{I C}$-results. Eng. Fract. Mech. 1984, 19, 1085-1093. [CrossRef]

40. Gao, X.; Dodds, R.H. Constraint effects on the ductile-to-cleavage transition temperature of ferritic steels: A Weibull stress model. Int. J. Fract. 2000, 102, 43-69. [CrossRef]

41. Ruggeri, C.; Dodds, R.H.; Wallin, K. Constraint effects on reference temperature, $T_{0}$, for ferritic steels in the transition region. Eng. Fract. Mech. 1998, 60, 19-36. [CrossRef]

42. ASTM E1921-10. Standard Test Method for Determination of Reference Temperature, $T_{0}$, for Ferritic Steels in the Transition Range; American Society for Testing and Materials (ASTM): West Conshohocken, PA, USA, 2011; pp. 1177-1198.

43. Koçak, M. FITNET fitness-for-service procedure: An overview. Weld. World 2007, 51, 94-105. [CrossRef]

44. BS EN ISO 21952:2012. Welding Consumables. Wire Electrodes, Wires, Rods and Deposits for Gas Shielded Arc Welding of Creep-Resisting Steels. Classification; British Standards Institution: London, UK, 2012.

45. ISO 14175:2008(en). Welding Consumables_Gases and Gas Mixtures for Fusion Welding and Allied Processes; International Organization for Standardization: Geneva, Switzerland, 2008.

46. BS EN ISO 4063:2010. Welding and Allied Processes. Nomenclature of Processes and Reference Numbers; British Standards Institution: London, UK, 2010.

47. JSME S 001-81. Standard Method of Test for Elastic-Plastic Fracture Toughness JIC; JSME Standard: Tokyo, Japan, 1981.

48. Kobayash, H.; Nakamura, H.; Nakazawa, H. Evaluation of blunting line and elastic-plastic fracture toughness. Fract. Mech. 1983, 420-438.

49. Nguyen-Duy, P. Relationship between critical stretch zone width, crack-tip opening displacement, and fracture-energy criterion: Application to SA-516-70 steel plates. Fract. Mech. 1981, 543-552. [CrossRef]

50. Miyamoto, H.; Kobayashi, H.; Ohtsuka, N. Standard method of test for elastic-plastic fracture toughness $J_{\mathrm{IC}}$ recommended in Japan. In Mechanical Behaviour of Materials, Proceedings of the Fourth International Conference, Stockholm, Sweden, 15-19 August 1983; Carlsson, J., Ed.; Elsevier: Duxford, UK, 1983; Volume 2, pp. 747-753.

51. Lai, Z.; Ma, C. Comparison of several methods of $J_{\text {IC }}$ determination. Eng. Fract. Mech. 1985, 22, 1117-1119. 
52. Cao, W.D.; Lu, X.P. On the relationship the geometry of deformed crack tip and crack parameters. In Application of Fracture Mechanics to Materials and Structures; Martinus Nijhoff Publishers: The Hague, The Netherlands, 1984; pp. 525-545.

53. Bicego, V.; Rinaldi, C. Fractographic Study of Toughness Variability in the Transition Region; Mechanical Engineering Publications: London, UK, 1991; pp. 459-475.

54. Dzioba, I.; Furmańczyk, P. Determining the critical value of fracture toughness using the measurement of the stretch zone width. In Proceedings of the 11th European Conference of Young Researchers and Scientists, Zilina, Slovakia, 22-24 June 2015; Volume 5, pp. 82-85.

C 2018 by the authors. Licensee MDPI, Basel, Switzerland. This article is an open access article distributed under the terms and conditions of the Creative Commons Attribution (CC BY) license (http:/ / creativecommons.org/licenses/by/4.0/). 